Saudi Journal of Economics and Finance

Abbreviated Key Title: Saudi J Econ Fin ISSN 2523-9414 (Print) |ISSN 2523-6563 (Online) Scholars Middle East Publishers, Dubai, United Arab Emirates Journal homepage: http://saudijournals.com/sjef/

\title{
State Civil Service Apparatus Mechanism in the Field of Treasury and Financial Asset Management Agency
}

\author{
Totok Priyandanu*, Stia Budhi, Jamaluddin
}

Master Program of Government Science, Lambung Mangkurat University, Banjarmasin, Indonesia

\author{
DOI: $10.36348 /$ sjef.2019.v03i11.012 \\ | Received: 09.11.2019 | Accepted: 16.11.2019 | Published: 19.11.2019 \\ *Corresponding author: Totok Priyandanu
}

\section{Abstract}

Apparatus State Civil bound by the obligation to carry out government duties. The demands of the public or organizations to obtain quality services continue to increase over time. The demand is growing in line with the growing awareness that citizens have the right to obtain or provided services. This article aims to describe the service ASN in particular on Treasury Sector Finance and Asset management Agency in North Barito regency in 2018. The study was conducted using a qualitative approach. In the tradition of qualitative research study serves as a research instrument. Data were collected at three stages; documentation, observation, and interviews. Data analysis was performed model of Miles and Huberman. Test the validity of the data was performed using triangulation techniques. The results of the study described that the State Civil Service Reform has implemented dimensional Tangible, Reliability, Responsiveness, Assurance and Empathy and its indicators. However, some indicators have not been run following the wishes of service users among other discomforts in the services area, less response service representatives to service users and customer complaints are not responded well and less friendly and courtesy of service personnel in providing service.

Keywords: State Civil Apparatus, quality service, and the service ASN.

Copyright @ 2019: This is an open-access article distributed under the terms of the Creative Commons Attribution license which permits unrestricted use, distribution, and reproduction in any medium for non-commercial use (NonCommercial, or CC-BY-NC) provided the original author and source are credited.

\section{PRELIMINARY}

State Civil Apparatus (ASN) must carry out the task of governance and development with faithfulness. Implementation of development undertaken by the State Civil Apparatus which is a national goal that has been mandated by Pancasila and the Constitution of the Republic of Indonesia (Homeland) therefore every State Civil Apparatus shall carry out their duties and functions with full awareness and responsibility. National Objectives to be achieved requires seriousness and hard work, it is necessary for employees who are honest and loyal, a good mentality, authoritative and qualified in performing organizational tasks. The attitude must be owned and maintained to develop into a good culture within the organization.

Financial management of the country/region in Indonesia has undergone many changes (improvements) in line with the spirit of the government's financial management reform to achieve the success of regional autonomy. It is characterized by the release of the financial sector package state laws and regulations for derivatives with the implementation of regional autonomy that has been issued is a package of legislation on state financial sector namely Law No. 17 of 2003 on State Finance, Law 1 of 2004 on State
Treasury and Law 15 of 2004 on the Management and Financial Responsibility State. Special rules governing financial management guidelines for a new area,

Financial management includes regional income and expenditure budget laid out in a system that can improve the implementation of the general duty of government and development tasks. The local budget includes direct and indirect expenditure harmonized and strengthened by ongoing budgetary planning. In the implementation of the regional financial administration Treasury Sector Regional Financial Management Agency North Barito district, where one of the main tasks and functions is issuing Fund Disbursement Order (SP2D) intending to maintain stability. Fund Disbursement Order (SP2D) following Regulation of the Minister of Interior No. 13 of 2006 and Payment Order (SPM) following Kepmendagri No. 29, 2002, Money and Payment Order (SPMU) following Regulation No. 21994 have similarities that function as a document used to disburse or transfer funds from the Regional Treasury Account to stamp his name on SP2D or SPM or SPMU. Following the provisions of regulations stated that the issuance of Fund Disbursement Order (SP2D) no later than two (2) 
working days after the submission of SPM either direct spending and indirect spending.

However, if the service can exceed the expectations of society, the kind of quality of these services can be categorized as a service that is highly qualified or highly satisfactory. While this type of poor service quality is the type of service that is far below standard or not according to the expectations of the public service expected. Along with it the demands of the public or organizations to obtain quality services continue to increase over time. The demand is growing in line with the growing awareness that citizens have the right to obtain or provided services. To realize the right of people or organizations that demanded good working effectiveness of government agencies. This article aims to describe the implementation of the service by the State Civil Apparatus.

\section{RESEARCH METHODS}

The method used by the researchers to collect data research [1]. Describing the State Civil Service Reform in the Treasury Sector Finance and Asset Management Agency North Barito regency. Enabling and inhibiting factors in the State Civil Service Reform Treasury Sector Finance and Asset Management Agency Barito Utara District following the formulation of the problem and research objectives. The method used to examine the condition of natural objects. Researchers are a key instrument, data collection techniques are inductive and qualitative research results further emphasize the significance generalization of qualitative research object is an object that is natural [2]. Primary data is taken directly from the informant/research subjects. The primary data obtained through interviews. Secondary data is data that is not directly derived from the informant. The research instrument used to collect data in qualitative research is the researchers themselves. Researchers as a means of sensitive and can react to any stimulus from the environment expected research. Technique meaningful or not for data collection through; 1) Observation studies regarding site conditions, 2) Documentation used for secondary data collection, 3) submitted to the informant interviews and question number five.

The data analysis technique used in this research is using qualitative data analysis techniques to follow the concept given by Miles and Huberman. First, the data reduction is defined as the process of selecting, concentration, attention on simplification, abstraction, and transformation of raw data that emerged from written records in the field. Second, the presentation of data in the form of a brief description or narrative text but it can be a chart, matrix, network and charts [3]. Thirdly, verification and data collection resulting in clarity of the research data. Examination of the validity of data other than the data to check or as a comparison against the data. The triangulation technique used by the researchers is to use triangulation techniques and engineering resources. Triangulation to test the credibility of the data is done by checking the data obtained through several sources. Triangulation technique to test the credibility of the data is done by checking the data to the same source with different techniques, ie the data collected from interviews, and checked by observation and documentation $[4,5]$.

\section{RESULTS AND DISCUSSION}

\section{Asn service of treasury finance and asset management agency}

ASN service at Treasury Sector Finance and Asset Management Agency Barito Utara researchers used five dimensions proposed by Zeithaml ie: Tangible, Reliability, responsiveness, assurance, and Empathy. Besides, there is a description regarding enabling and inhibiting factors On the State Civil Service Reform Treasury Sector Finance and Asset Management Agency North Barito regency. The government set up to provide services to the community. The government is not held to serve themselves but to serve the community and create conditions that enable every member of the community to develop the ability and creativity to achieve a common goal [6].

Therefore, Service is a process; product and outcome are unique as required by humans and processed following the aspirations of man [7]. Service is the fulfillment process through the activity of others directly. Service to the community is the activities carried out by a person or group of people with a grounding factor of material through the system, procedures and specific methods to attempt to meet the interests of others in his own right [8]. Aside from being a service process, the service is also an art. As an art, art is the art services that are owned by government personnel in carrying out its duties and functions.

Service or services produced quality if it can be said is designed and manufactured following the wishes of the user community and is distributed through service and well and can be put to good use to meet the needs of the community [6]. Thus there is a relationship between service quality and satisfaction of the user community, the orientation of the quality of service to the community with a focus on the achievement of the correspondence between what is expected with what is obtained by the public. The quality of public services into one barometer of the success of the implementation of regional autonomy. One reason for the implementation of regional autonomy is that the public services provided by the state can take place in a more efficient and targeted.

Associated with regional autonomy, which has implications for democratization, including in terms of public service performed. People are starting to critical and could determine how the public service types desired. The growing community of civil society 
towards the role of government bureaucracy requires more adaptive to the strengthening of the rights of the public in the delivery of services more broadly and balanced. Increasing demands of society and public services are effective, efficient and satisfying of government employees as public servants increasingly popular. It is associated with the development of the needs, desires, and expectations of a growing and increasingly sophisticated. Society as a subject of service no longer attracted to the services convoluted, long and risky due to the long bureaucratic chain. People want freshness services, and able to understand the needs and desires are fulfilled in a relatively short time.

The desire of the need to respond to and fulfilled by the agencies that are engaged in services, if the activity want to have a good image, for the management needs to reevaluate the service aspect which has been granted in accordance with the needs and desires of the community served, or just the opposite is still there the gap between the services provided by the service expected by society. Disparities indicate a less vibrant service quality, thereby potentially lowering the overall agency performance [9]. The quality of public services always has dynamics, science, and technology also progressing rapidly. Along with this, of course, concepts, dimensions, indicators of the quality of public services changes along with the changing times [3]. Ability to adapt to these changes, a capital for policymakers to constantly improve the quality of public services. The ability to improve the quality of public services can improve public trust in the organizer's office or SKPD.

The quality of public services provided by government officials, there should be criteria that indicate whether a given public service can be good or bad, qualified or not. Generally, that often appear in the public eye is a service provided care workers. The concierge service is spearheading the forefront of dealing directly with the public. Therefore, the leading officer should have professionalism. Assessing the quality of public services provided by government officials can not be avoided, even a measure of the quality of service that can be explored from the criteria of the dimensions of quality of public services.

Regulation of the Ministry of Internal Affairs in 2006 showed that the services related to the product of public organizations are a public service. Hence product quality services to the demands of service providers. In this case, the performance of public services consists of: Production is a measure of the ability of the organization to produce the output required by the environment; Quality is the organization's ability to meet customer expectations. Efficiency is the best comparison between the output and input; Flexibility is a measure that indicates
Tanggang organization to the changing demands of internal and external.

Satisfaction refers to the feelings of employees towards work and their role in the organization. Competition describes the organization's position in competition with other similar organizations. Development is a measure that reflects the ability and the responsibility of the organization in expanding the capacity and potential for growth through the investment of resources and survival is the ability of an organization to exist in the face of all the changes.

Measuring the quality of public services is either not enough just to use a single indicator, but of necessity must use a multi-indicator or multiple indicators in implementation. Because the dimensions of service presented above, greatly affect the quality of services provided by the authorities, in the areas of governance and development services; economics; the field of education; health; social field; public welfare; and the area of land and so on [10].

The quality of public services consists of four dimensions, namely the dimensions of efficiency, effectiveness, fairness, and responsiveness. Each dimension consists of several indicators. Dimensions efficiency, the indicator is successful public service organizations at a profit, making use of production factors and considerations derived from economic rationality [11]. Dimensions of effectiveness, the indicator is: whether the purpose of the establishment of a public service organization that is achieved; It is closely related to technical rationality, values, mission, goals of the organization, and function as an agent of development. Dimensions of justice, the indicator is the distribution and allocation of services organized by public service organizations, and for the dimensions of responsiveness, the indicator is responsiveness to the needs of society.

\section{Factors hindering the State Civil Service Reform}

In the service process does not always go as expected, there are factors that hinder the process of the implementation of Service Apparatus State Civil (ASN) At the Board of Finance and Asset Management North Barito district of researchers associated with the theory Zeithaml-Parasuraman. Berry [12, 13], Inhibiting tangible dimension (intangible) contained in the comfort indicator ministry. On this indicator is still not optimal in providing services to end-users such conditions can be seen in the lack of waiting rooms or availability of seats for the queue, causing the service users to sit too close to the other services. This facility gives effect to service at the agency's Office of Finance and Asset Management North Barito regency.

The factors that affect the quality of public services, among others; (1) Work Motivation bureaucracy and apparatus; (2) The ability of the 
apparatus; (3) oversight / social control; (4) The behavior of bureaucracy / apparatus; (5) Communication, disposition and bureaucratic structure and organizational communication climate and the flow of information; and (6) The restructuring of the organization. Each of these factors affects the quality of public services. That is, in general, it can be said that all six of these factors predominantly affect the quality of public services, in addition to other factors. The quality of public services is a dynamic condition associated with products, services, people, processes and environments where quality ratings are determined at the time of the delivery of public services. The concept of quality of service can be understood through consumer behavior,

\section{CONCLUSION}

The State Civil Administrative Services Treasury Sector Finance and Asset Management Agency Barito Utara can be judged by the quality of service that consists of five dimensions namely; Tangible dimension (intangible), this dimension has indicators of performance, comfort, human resources, facilities, and employee discipline, but there are indicators that have not been fully implemented is about comfort in the services. Dimensions Reliability has the precision indicator, clear service standards, capabilities and expertise that have been applied. All indicators have been applied and following what is expected by users of the service, and this is evident in the absence of complaints from service user's related indicators of reliability dimension. Dimensions Responsiveness has an indicator responds, fast, precise, accurate, timely and responsive to all complaints of service users. But indicators have not been fully implemented, namely, the lack of service personnel response to user service and customer complaints are not responded well.

Dimensions Assurance (guarantee) that has a guarantee of timely indicators and guarantee fees. All indicators have been applied and following what is expected by users of the service, and this is evident in the absence of user complaints related service assurance dimension indicator. Dimensions Emphaty indicator has put the interests of users of the service, friendly, polite, non-discriminatory, serve and respect. but some indicators have not been fully implemented, namely the less friendly and courtesy of service personnel in providing service. Factors inhibiting the State Civil Administrative services In Treasury Sector Finance and Asset Management Agency North Barito regency is still a lack of comfort in the services, concierge services less responsive.

\section{REFERENCES}

1. Arikunto, S. (2002). Manajemen Penelitian. Jakarta: Rineka Cipta.

2. Afifuddin., \& Ahmad, B. (2009). Metodologi Penelitian Kualitatif. Bandung: Pustaka Setia.

3. Mulyana, D. (2001). Metodologi Penelitian Kualitatif: Paradigma Baru Ilmu Komunikasi dan Ilmu Sosial Lainnya. Bandung: PT Remaja Rosdakarya.

4. Satori, D. (2011). Metode Penelitian Kualitatif. Bandung: Alfabeta.

5. Nasution. (2003). Metode Penelitian Naturalistik Kualitatif. Bandung: Tarsito.

6. Hardiansyah. (2011). Kualitas Pelayanan Publik. Yogyakarta: Gaya Media.

7. Sinambela, L. P. (2010). Reformasi Pelayanan Publik Teori, Kebijakan dan Implementasi. Jakarta: PT. Bumi Aksara.

8. Moenir, H. (2002). Manajemen Kantor. Jakarta: Yudistira.

9. Dwiyanto, A. (2010). Manajemen Pelayanan Publik: Peduli, Inklusif, dan. Kolaboratif. Yogyakarta: Gadjah Mada University Press.

10. Ekowati, L. (2005). Perencanaan, Implementasi dan Evaluasi atau Program. Surakarta: Pustaka Cakra.

11. Supranto. (2006). Mengukur Tingkat Kepuasan Pelanggan atau Konsumen. Jakarta: Rineka Cipta.

12. Mulyadi, D. (2016). Studi Kebijakan Publik dan Pelayanan Publik. Bandung: Alfabeta.

13. Lukman, S. (2011). Manajemen Kualitas Pelayanan. Jakarta: STIA LAN Press. 